\title{
The Implementation of Local Wisdom to Improve the Health and Quality of Life the Hypertension Family as a New Strategy for Early Prevention of Stroke
}

\author{
Marlina $^{1,2}$, Badaruddin ${ }^{3}$, Fikarwin Zuska ${ }^{3}$ \&Rahayu Lubis ${ }^{1}$ \\ ${ }^{1}$ Faculty of Public Health, Universitas Sumatera Utara, Medan 20132, Indonesia \\ ${ }^{2}$ Faculty of Nursing, Universitas Syiah Kuala, Banda Aceh 23111, Indonesia \\ ${ }^{3}$ Faculty of Social and Political Science, Universitas Sumatera Utara, Medan 20132, Indonesia \\ Correspondence: Marlina, Faculty of Public Health, Universitas Sumatera Utara, Medan 20132, Indonesiaand \\ Faculty of Nursing, Universitas Syiah Kuala, Banda Aceh 23111, Indonesia. Tel: 62-812-691-4547. E-mail: \\ linamnur7776@gmail.com
}

Received: October 28, 2019 Accepted: December 10, 2019 Online Published: January 30, 2020

doi:10.5539/gjhs.v12n2p51 URL: https://doi.org/10.5539/gjhs.v12n2p51

\begin{abstract}
Indonesia is well known as a country which has high ethnic diversity. Thus, each ethnic specifically has a local wisdom as their own identity. However, the economic growth, globalization, and modernization have eroded the local wisdom in which it is potentially forgotten by the next generation. The modernization also has been proved changing the behavior, lifestyle, and live quality of society. As the result, Hypertension are documented as the highest case diseases generated by the change of behaviour, lifestyle, and lack quality of life. However, the hypertension is possibly controlled by the intervention of life-style and improving the quality of life. This present study aims to implement the local wisdom of Aceh to improve the quality of life as new strategy to early prevention of stroke disease. The research design using Participatory Action Research including reconnaissance, planning, action, evaluation, and reflection based on Aceh local wisdom are specifically used as a new approach to reach the goal. The result shows that the local wisdom can be used as the main reason to change the society behaviour. The implementation of local wisdom potentially become the solution, because the society, especially the one who have the history of hypertension coming from their family, can empower family health problem by providing high attention to family health problem. Additionally, the local wisdom encourages the society to check their health status as control, whereas most of participant is only visiting the health center when they did not feel good. The result also proved that the local wisdom can initiate the society to modify their own environment, indicating the increase of awareness about the importance of cleaning the environment. The successful implementation of local wisdom should be supported and developed to follow the modernization without losing its identity because the fast growing of globalization cannot be hold but can be well maintained.
\end{abstract}

Keywords: quality of life, hypertension, stroke, aceh, local wisdom

\section{Introduction}

Globalization and modernization have shifted the incident of disease from infectious disease to non-infectious disease such as stroke, coronary heart disease, diabetes mellitus, and cancer(World Health Organization/WHO, 2015), Lifestyle and behavior changes which mostly loss control become the initial approach to non-infectious disease. Additionally, the dietary consumption pattern followed by the less physical exercise, and behavioural stress aggravate the disease initiation (WHO, 2015). To be more specific, stroke become the most common disease occurred after diabetes mellitus initiated by lifestyle and behaviour changes. World Health Organization (WHO) reported that the number of stroke cases annually increase around the world. The increase of cases is positively correlated with the number of sufferers died. American Heart Association is also reported that several sufferers of stroke have the age less than 45 years old which is the golden age of generation (American Heart Association/AHA, 2010) (Goldstein et al., 2011). The high number of stroke incidences poses a threat to all society level including teenager and need the further prevention and progress in reducing its number.

In Indonesia, stroke is estimated as the first leading of disease suffer by Indonesian society. Approximately 500.000 people in Indonesia have a stroke each year, more than 2,5 percent of 125.000 people in Indonesia died 
because of stroke, and more than 350.000 people annually become stroke survivor (Yayasan Stroke Indonesia, 2012). The ministry of Health Republik Indonesia (In bahasa, Kementeriankesehatan RI) (2014) reported that one of seven people died because of stroke every year. Literature review shows that high blood pressure or well known as hypertension is the most contributed factor of stroke followed by diabetes mellitus, and coronary heart disease (Smeltzer\& Bare, 2010). It is also supported by American Heart Association and American Stroke Association (2014) which reported that high blood pressure, high cholesterol, and aterosklerosis are the main factors of stroke incidences, of which lifestyle is the initial approach of all these factors happened.

Lifestyle is proposed becoming the most high-risk factor occurring stroke in which several factor such as non-health dietary consumption, less physical activities, alcohol consumption (food and drink), behavioural stress, coronary heart disease, smoking activities including passive smoker, cholesterol background, and diabetes mellitus detaillyprefered as stroke attack factor (Adegoke et al., 2012). Moreover, each factor has specific prevention, of which the basic knowledge and early action of health management poses as the most important way to suppress stroke incidence in the world society (Noorkhairina et al., 2013). In addition, the fast increase of stroke incidence is partly because of poor community knowledge of stroke risk factor and its warning sign (Donkor, 2018). Therefore, providing a counseling and comprehensive meeting with community become a good start to improve basic knowledge of stress risk and one of five step prevention (Clark, 2011).

In this study, we tried to develop a early prevention of stroke by improving the quality of life using local wisdom implementation. To be more specific, the target of this study was the family with have a background of hypertension which has the strongest risk of stroke. The present study is focused on improving basic knowledge of stroke and the way to do early prevention of stroke by modify the environment, daily activities, and dietary consumption. Moreover, the role of local wisdom is used as the preferences which used to interpret how this local wisdom can be made as the role to manage the elderly who has better life with less stroke incidence. Modifying and changing the activities as family empowerment is expected providing a better quality of life. Additionally, the family centered intervention is also applied to reach the goal. Even this way is not suitable in some place over the world, it is considered as an effective way in the studied area a due to cultural appropriateness.

\section{Method}

\subsection{Research Location and Period of Time}

The research was conducted in the health center (Puskesmas) of UleeKareng in Banda Aceh, the capital city of Aceh Province, Indonesia in the period between February 2017 to October 2018. The main reason choosing Banda Aceh was since Banda Aceh is the highest stroke incidence in Indonesia (Kemenkes RI, 2013).

\subsection{Study Population}

The first step of research was conducted by study the population target. The participant was chosen based on the health and personal background which obtained from the health center data, and invited to come to health center if they met the following criteria: agreed to follow all the research process and complete all the survey, having a family who has hypertension or stroke background, Acehnese (the local wisdom will be implemented), can clearly communicate with us/researcher, and having a strong relationship with the family members who have hypertension or stoke. The choose of participant use a specific judgemental theoretical/purposeful method (Polit\& Beck, 2016). Furthermore, we selected the participant based on inclusion criteria and conducted a focused group discussion to interpret the aims and goal of this research, knowing the most participant health problem, and discuss about the possible way to solve to problem. After the discussion, we visit participant place (work area and home) to build a good chemistry and improve the confidence and trustiness of participant.

In the first week, we have continuously contacted and visited the selected participant and did some discussion. The discussion was two ways discussion with open ended interview which focused on develop the participant trustiness and digging out more information of health background, activities, and personal information. We gave an open space to participant to tell all of their problem. To make the process more comfortable, all the process including interview was conducted by unstructured process for 30 minutes to provide a flow conversation without any compulsion and tend to be more informal and open-ended (Denzin\& Lincoln, 2009).

This first step was conducted until the saturation information achieved, meaning all the obtained data accurately. Furthermore, several activities are conducted by doing discussion with the participant. Most of obtained data which we want to achieve in this step are the information about the basic knowledge of participant about how the family health information, identify their experience and knowledge about family health information and how they handle the family health problem. All the obtained information is then structured to form a transcript based on the research purposes. Besides, we also observe the life quality of participant family and learn about how they 
empower the participant family before the treatment provided. All the information become the control to see the effect of treatment after the research conducted.

\subsection{Treatment}

\subsubsection{Planning the Treatment}

Planning is conducted based on the obtained information achieved at the study population. We invited the selected participant and do a comprehensive meeting about the next step of research. In this study, the treatment given to the selected participant is based on the discussion between the researcher and participant, of which local wisdom is tried to be implemented. Both side (researcher and participant) should agree about the future treatment, in which the goal should empower the life quality of family participant and improve the family member awareness about how the importance of family health management is. Moreover, we proposed the participant to regularly visit the health center to check their family health information during the research period and provide them about how to handle the hypertension and prevent the stroke early.

\subsubsection{Treatment Processes}

The treatment process is a health intervention conducted by researcher to the selected participant which have agreed to follow all the research process. The health intervention including attending the counseling and checking their health status. The counseling is focused on discussion about the family health management such as how the family member knows the initial symptoms of hypertension and stroke, how taking a decision of emergency actions when face the stroke attack, how taking care the family member who have stroke, how modifying the environment to be proper environment (health and good in sanitation), and how family member use the health facility to prevent the hypertension and stroke disease.

\subsubsection{Observation, Evaluation, and Reflection}

The treatment process is a simple process but having a powerful effect for improving life and health quality. Observation and Evaluation play the important role to ensure the treatment is implemented. The researcher conducted the observation and regularly check their development in family health management especially checking the progress about how they maintain and take care to the family member who has a hypertension background. Every single activity is also documented by both researcher and participant to record the progress of any treatment and be evaluated by both sides through doing a weekly meeting in the health center.

The evaluation is carried out by deeply discussion through unstructured interview. The interview aims to obtain the accountable information and data to develop a further strategy of family health empowerment to do early prevention of stroke.

The reflection is the final step of research using Participatory Action Research to see if the treatment is successfully implemented by the selected participants. The output of the reflection step is a strategy of family health empowerment to do early prevention of stroke, especially in the studied area.

\section{Results}

\subsection{Location and Population Characteristics}

The health center or in Bahasa it is called as Puskesmas is a community health center that become the health technical basic service unit in village or district. The Ministry of Health Republic Indonesia in the Judgement of Minister of Health, No. 128/Menkes/SK/II/2004 is defined Puskesmas as a functional health organisation which become the center of community-based health development which have the responsibility to educate community and provide community health service. From the definicion, it can be well seen the importance of health center which not only provide the health service but also educate the community.

The health center or PuskesmasUleeKareng as the studied area has 615 kilometers of working area which consists of nine (9) villages and 30 sub-districts with the total of 25.170 residents (12,792 men and 12.378 women) and 7,604 families as their responsible community.

The choosing of Aceh province as the studied area has a special reason than because of high number of stroke incidences. It is because of the rich of culture, hospitality, and religious. The aceh community means Family as the powerful things which can control the behavior. In general, Acehnese see the lineage based on father (patrilineality) in which most of Acehnese man is paternalistic. This makes man becoming more dominant than woman and the highest decision will be taken by the man as the leader of family.

The patrilineality characteristics of Acehnese also affect in the decision maker of health management. In a family, a father or husband as leader will ask his wife or a mother to manage the household including health. The woman 
who be a manager of house have a responsibility to take care if there is a family member who get a sick or become a disease survivor. However, this proper management of quality of life and dietary consumption does not implement in a good management which potentially avoid the disease which initiated by the quality of life like hypertension and stroke in early time.

In healing process, Acehnese also has a special treatment which call meukaoiorbernazar (in Bahasa Indonesia) which basically a promise to God doing something such as praying or donating something to other people if they got better or being health. The community also visited some the religious place such as the cemetery of Syiah Kuala and Mesjid Raya which are also the iconic of Aceh province. This behavior is also identified as fatalistic,indicating the belief and family trustiness can be managed and potentially become the new approach to do the early prevention of stroke.

The community of Aceh have a unique belief which come from the islamic belief (most of Acehnese is moslem). The community considers illness as the will of God Almighty, of which illness is the way of God forgives their sins If they die because of having a disease, they will be a sinlessness. They believe that God creates illness and treatment. Thus, we as His creation should follow what He want to do for us, and just do our best and pray. There are several families also believes on mekaoi(in acehnese language) or bernazar (in Bahasa Indonesia) which specifically pray to the God and make a promise to Him if they get a healthy after their promise, meaning that they make a deal to the God. Several activities such as doing sacrifice to chicken in the cemetery of Syiah Kuala which believe that it is a sanctuary. The worst facts come from the people who keep doing a wrong dietary consumption and do fewer physical activities which potentially initiate hypertension and stroke disease, but when the disease come, they believe that it come from the God and feel surrender. However, it is getting wrong, because God will never change our destiny if we do not change it by ourselves. This case is unique because in one part, the belief can be a powerful force, but if it is not educated well, it can be something sustainably wrong. The education activities such as counseling can improve and develop the wrong belief to be a good strategy through combining the traditional belief as local wisdom and the treatment to early prevent the disease.

\subsection{Selected-Participant Characteristics}

The study began by doing a sampling method using the judgmental theoretical / purposeful sampling. There are 32 participated as the sample who are willing to contribute, and commitment sign an informed concern. Furthermore, the sampling is based on some characteristics such as having family members who are hypertensive, Acehnese, and do not have any speech or hearing impairment/disabilities.

The characteristics of selected participant is shown in Table 1. The most ages of participant are in range 26-35 years old which is young adult with a specific number of $46.9 \%$. In basic, this age should have a good physical body condition. However, the result shows that most of this age potentially have a high risk of hypertension due to the family relationship. The second highest number of selected participants is adult which have $28.1 \%$ followed by teenager (15.6\%), elderly $(6.3 \%)$. and late elderly (3.1\%). Basically, the participant is a family member who have a hypertension background meaning that they have their family member as hypertension or stroke survivors. The high number of each categories does not mean that they have a hypertension, but they possibly have a risk on it. The participant who join to this research also as the family who take care to their family member. It is shown by women as the most dominant participant (79.1\%) which mostly have responsibilities to take care their family at home, while men only contribute $21.9 \%$ who take care their family members to health center.

The data of characteristics also show that most of participant who join this research has a relationship as child $(53.1 \%)$ to the family member who has hypertension and stroke background. It is also caused by the tradition of Aceh, in which the daughter has a responsibilities to take care their parents. In addition, the other participants are wife or a mother and husband which mostly take care their couple to take care or just do some check in health center.

In education level, most of participant is educated in which $59.4 \%$ and $37.5 \%$ of participant have moderate, and high levels, respectively. there is only 3.1\% (1 participant who have low education level. Furthermore, the occupations of participant are consisting of $53.1 \%$ as private employee or entrepreneur which is correlated with the facts that most of participants are women. It is also supported by the facts that housewife become the second occupation of selected participant $(40.6 \%)$. There is only $6.3 \%$ of participant who work in government. The low number of governments is because of most of participant who take care their family should have a flexible schedule, where the government employee does not have it. 
Table 1. Participant demographic characteristics

\begin{tabular}{|c|c|c|}
\hline Parameters & Number & Percentage (\%) \\
\hline \multicolumn{3}{|l|}{ Age } \\
\hline 1. Teenager & 5 & 15.6 \\
\hline 2. Young Adult & 15 & 46.9 \\
\hline 3. Adult & 9 & 28.1 \\
\hline 4. Elderly & 2 & 6.3 \\
\hline 5. Late Elderly & 1 & 3.1 \\
\hline \multicolumn{3}{|l|}{ Sex } \\
\hline 1. Woman & 25 & 79.1 \\
\hline 2. Man & 7 & 21.9 \\
\hline \multicolumn{3}{|l|}{ Relationship } \\
\hline 1. Child & 17 & 53.1 \\
\hline 2. Mother/Wife & 8 & 25.0 \\
\hline 3. Father/Husband & 7 & 21.9 \\
\hline \multicolumn{3}{|l|}{ Education } \\
\hline 1. Low (Elementary) & 1 & 3.1 \\
\hline 2. Moderate (High School) & 19 & 59.4 \\
\hline 3. High (College) & 12 & 37.5 \\
\hline \multicolumn{3}{|l|}{ Occupation } \\
\hline 1. Governement Employee & 2 & 6.3 \\
\hline 2. Private Employee/Entrepreneur & 17 & 53.1 \\
\hline 3. Housewife/unemployee & 13 & 40.6 \\
\hline \multicolumn{3}{|l|}{ Smoking Activity } \\
\hline 1. Active & 7 & 21.9 \\
\hline 2. Passive & 16 & 50.0 \\
\hline 3. Non-active & 9 & 28.1 \\
\hline
\end{tabular}

Last characteristics is smoking activity which have a correlation to the risk of hypertension or stroke incidences. Most of the participant is passive smoker (50.0\%), followed by non-smoker (28.1\%), and active smoker (21.9\%). Most of participant is not a smoker because of women. The small percentage of smoker is only done by the men participants who are all active smoker.

\subsection{Family Health Empowerment Strategy}

The strategy is arranged as a matrix which explains about the implementation of hypertension family health empowerment in preventing stroke in the studied area (working area of Puskesmas, UleeKareng, Banda Aceh). This matrix is arranged with purpose: family empowerment to know the family health problem; strategy to make a decision of future treatment; strategy to take care of family who have a health problem; empower the family health by modifying the environment (home, working place, etc); and introduce the health center facility which can be used to improve the family health quality. The specific matrix which have been arranged is shown in Table 2. 
Table 2. Matrix used in interview and focus group discussion

\begin{tabular}{|c|c|c|}
\hline Sub-category & Sub-theme & Theme \\
\hline $\begin{array}{l}\text { The family member can explain about the incidence of stroke (mate } \\
\text { siblahbadan, leumoh, saketulee, hana sue.) }\end{array}$ & $\begin{array}{l}\text { Stroke signs and } \\
\text { symptoms }\end{array}$ & \multirow{4}{*}{$\begin{array}{l}\text { The family member } \\
\text { understands and know their } \\
\text { role in empowering the family } \\
\text { health to prevent the } \\
\text { hypertension and stroke }\end{array}$} \\
\hline $\begin{array}{l}\text { The family member can explain about the factor initiating of } \\
\text { hypertension like clogged blocked artery and the effect of hypertension } \\
\text { and stroke such as aneurysm and artery rupture. }\end{array}$ & Initial factor & \\
\hline $\begin{array}{l}\text { The family member can avoid their family to be active and passive } \\
\text { smoker, avoid behavioral stress, modify dietary which potentially } \\
\text { stimulate hypertension (substitute meat with fish), and do some exercise } \\
\text { or praying which can be an exercise. }\end{array}$ & Prevention & \\
\hline $\begin{array}{l}\text { Obey all the medical treatment including consume medicine and } \\
\text { suggestion ordered by doctor and health practitioner. }\end{array}$ & Treatment & \\
\hline $\begin{array}{l}\text { Each family member provides high respect to each family and know } \\
\text { their portion to make any discussion. Reminding each member to do } \\
\text { medical consultation and do balanced diet together. }\end{array}$ & Discussion & \multirow{3}{*}{$\begin{array}{l}\text { The family member can } \\
\text { decide about the family health } \\
\text { management }\end{array}$} \\
\hline $\begin{array}{l}\text { The family member can understand and implement the local wisdom of } \\
\text { habagophandidengehabadroehanabutoi }\end{array}$ & Not dominant & \\
\hline $\begin{array}{l}\text { The family member shows a high respect to all the other family member. } \\
\text { One of the ways is: make wife or wife as the partner or in Aceh language } \\
\text { ureuinongpeumulia. }\end{array}$ & Equality & \\
\hline $\begin{array}{l}\text { Reminding the family member who have a health family to consume its } \\
\text { medical treatment (medicine) }\end{array}$ & $\begin{array}{l}\text { Consuming } \\
\text { medicine }\end{array}$ & \multirow{4}{*}{$\begin{array}{l}\text { The family member can } \\
\text { handle and take care the other } \\
\text { member who is sick or stroke } \\
\text { survivor }\end{array}$} \\
\hline $\begin{array}{l}\text { The family member or partner provide a health food with high nutrients, } \\
\text { high fiber, but less cholesterol such as fruit and vegetable. }\end{array}$ & Control dietary & \\
\hline $\begin{array}{l}\text { Each family member well understands the physical exercise such as } \\
\text { gymnastics, praying (in Muslim, praying is also doing a physical } \\
\text { exercise), and fasting sunnah to obtain a fit body. }\end{array}$ & Physical activity & \\
\hline The family avoid becoming active and passive smoker. & Non smoker & \\
\hline $\begin{array}{l}\text { The family member can provide a comfortable environment, unstress- } \\
\text { fullness, clean, no slipper, bright, and safe. }\end{array}$ & $\begin{array}{l}\text { Safe } \\
\text { comfortable }\end{array}$ & \multirow{6}{*}{$\begin{array}{l}\text { The family member can } \\
\text { empower the environment by } \\
\text { modifying their home and its } \\
\text { surrounding to be safe and } \\
\text { comfortable }\end{array}$} \\
\hline $\begin{array}{l}\text { There is a continuously plan for doing a recreation or just simply visit } \\
\text { the other family. }\end{array}$ & Recreation & \\
\hline $\begin{array}{l}\text { The family member does an art or play music such as rebana, rapai, } \\
\text { cumucop(Aceh traditional music tool). }\end{array}$ & Creativity & \\
\hline The family member joins the socio-society activities. & $\begin{array}{l}\text { Social and society } \\
\text { supports }\end{array}$ & \\
\hline $\begin{array}{l}\text { The family member invites their family who has a disease joining a } \\
\text { community meeting or in Aceh tradition called } \\
\text { wirid/zikirakbarratepsiribee. }\end{array}$ & $\begin{array}{l}\text { Recitation } \\
\text { community }\end{array}$ & \\
\hline $\begin{array}{l}\text { The family member supports their family who has a hypertension to do } \\
\text { their hobby or show their talent such as farming, singing, planting, etc. }\end{array}$ & Talent & \\
\hline $\begin{array}{l}\text { The family member empowers to support and accompany their family } \\
\text { who has hypertension to do a regular check and consult with the health } \\
\text { team of health center. }\end{array}$ & Accompaniment & \multirow{2}{*}{$\begin{array}{l}\text { The family member can } \\
\text { effectively use the health } \\
\text { facility in health center }\end{array}$} \\
\hline $\begin{array}{l}\text { The family member enriches their knowledge about stroke by providing } \\
\text { some references (book, journal). }\end{array}$ & Reading material & \\
\hline
\end{tabular}




\section{Discussion}

\subsection{Participant Characteristics}

The most dominant of participant in this research has the age of 26-35 years old, in which this age is called as golden age because of most people on this stage has high productivity and activity, mature, and good in analysis. Compared to the other characteristics, the young adult potentially influences their family member to develop their quality of life in order to achieve the early prevention of stroke. In addition, the young age level is a stage where people started their new life after being teenager in which providing the well education about how to have a proper life tends to move a community quality in the future with high quality socio-society life with low number of hypertension and stroke disease. The young adult is also known as the stage where they have a wisdom to obtain the decision which is good in health management and avoid their ego and assume that family is everything. It became a good investment because they provide a high responsibility to their family, including managing the family health quality. The young adult development is also a stage where the cognitive performance is in its peak, adaptive, and having a high logic critical thinking (Hurlock, 2011).

The family member suggests taking care the member who has a hypertension background because the ages of them is a unchangeable factor. Stroke disease is a disease where most of its survivor come from elderly or late elderly and mostly coming after menopause for woman. Stroke is also initiated or come from the other disease such as coronary heart disease, diabetes mellitus, which initiated by the wrong or unhealthy dietary consumption. The increase of stroke frequency is also correlated by the increase of age or aging, in which the human body, especially organs faces functionalize decline including blood vessel and brain. Normally, the blood vessels become inelastic, especially the endothelial part that experiences thickening in the intima, resulting in a narrower lumen of the blood vessels and an impact on decreasing blood flow to the brain (Senoo, 2015).

\subsection{The Improving Process of the Quality of Life the Hypertension Family to Early Prevent Stroke}

The process of empowering the health of families with hypertension in an effort to prevent stroke in the UleeKarengpuskesmas area in Banda Aceh, consists of: how families recognize health problems, decide on appropriate actions, care for family members, modify the environment and utilize health facilities. The form of empowerment undertaken by researchers is through the introduction of family health problems through the involvement of village cadres, and providing health education on how to recognize family health problems, conducting regular health checks every Friday or Saturday at the village hall in rotation together with health workers, forming hypertension sufferers club to communicate with each other sufferers, invite family members to exercise regularly to eat foods that are high in carbohydrates and protein but eat foods that contain lots of fiber, reduce stress levels in accordance with local customs and culture of the Acehnese people and religious values of the general public Islamic religion by way of many obligatory worship and sunnat worship, dhikr/meuratep, do silaturrahim or visiting activities which means by making friends will prevent disease or prolong life.

The results showed that hypertensive families are able to recognize family health problems in preventing stroke, participants understand about stroke, causes, symptoms or signs, complications and how to prevent stroke. Before being counseling during this research, participants were not fully aware of the problem of hypertension at risk of stroke and still ignored family members who were hypertensive, did not look for accurate information and considered hypertension as an ordinary disease and without any symptoms, did not choose and sort out food for sick family members. According to the result of interview, focus group discussion, and direct observation, it is necessary to explain the basic concepts of stroke to participants and involve family members to take part in health awareness about the meaning of stroke, its causes, symptoms or signs, complications and how to do early prevention of stroke. Providing early information motivate families to actively participate in preventing stroke, by managing hypertension properly.

The form of empowerment for families is conducted by providing health education to families about the importance of knowledge about stroke. It become a must since most of Acehnese give the family leader (husband) to make decision of health management including treatment to their family member who is a hypertension or stroke survivor. It is also important to build the confidences of hypertension or stroke survivor and trust their family who care more or care about family members than family members who care less. A good, quick, and appropriate deliberation can also be made in decision making for the care of stroke sufferers.

Stroke prevention can also be done through providing insight into the thinking of family members to believe and trust in medical treatment by utilizing facilities that have been provided by the government and avoid to belief meukaoi, sanctuary, cemetery. or a religious monument because visiting these places cannot medicate your disease. These places (sanctuary, cemetery, or religious status) can be a place to spend their free time during holiday or just 
doing their me time to obtain relax feeling and soul.

Providing information to family members of patients has an important role and function to make the family aware that family support has a significant effect on healing. The family is the spearhead of sufferers where support from the family, increase the confidence to be healed through psychological supports. Phycologicalsupport as the comfort area enhance the producing of adrenaline and endorphins hormones which indirectly neutralize blood pressure which is good for hypertension and stroke healing. It can be said that supporting the suffers reduce their stress which positively correlated to improve their metabolism and reduce the hypertension possibilities.

On the other hand, the early prevention of stroke can be achieved by regularly use the health facilities. The regularly health check through using health facilities can early detect illnesses, so that the family member can prepare the future treatment needed. Furthermore, it is also important to do checking up since the health center is quite far from the community resident. Thus, the early detection can predict possibility first aid or the time to reach the health center. The distance between the house and the health center also greatly influences the degree of pain and severity of an illness, such as hemorrhagic stroke, of which the wider the area of the bleeding, the deeper the level of consciousness (stupor even to coma). the time is crucial to the decision to use health facilities so further action can be carried out immediately.

Families as people closest to sufferers can provide support to take advantage of health facilities, in terms of early prevention of stroke. Friedman (2010) reported that the family has some support for family members namely: informational support where the family has the responsibility of advising, providing constructive advice and seeking information about reading sources about the state of family health; emotional support where family is put as a safe and peaceful place to rest and learn and help control emotions, including maintaining emotional relationships, supporting manifested in the form of affection, the existence of trust, attention and listening or being listened to when expressing their feelings.

It is supported by the fact that most of communities in Aceh is belief in Islam in which taking care the family become the responsibilities of any family member which is managed by holy Al-qur'an as the main source of references of Islamic. Therefore, what we want to suggest, and implement is in accordance in what most of communities believed. Additionally, Aceh is a special autonomous region in which the government refers to the qanun or regional regulations that refer to the holy Al-quran and hadith.

\section{Competing Interests Statement}

The authors declare that there are no competing or potential conflicts of interest.

\section{References}

Adegoke, B. O. A., Olaniyl, O., \& Akosile, C. O. (2012).Weight Bearing Asymmetry and Functional Ambulation Performance in Stroke Survivors. Global Journal of Health Science, 4(2). 87-94. https://doi.org/10.5539/gjhs.v4n2p87

American Heart Association and American Stroke Association. (2010). Published Newly Revised Guidelines for the Primary Prevention of Stroke in America. Retrieved from https://www.heart.org/idc/groups/heart-public/@wcm-/@adv/documents/downloadable/ucm_305054.pdf

American Psychological Association. (1972). Ethical standards of psychologists. Washington, DC: American Psychological Association. https://www.apa.org/ethics/code/principles.pdf

Amirood, M. M., Thagdisi. M. H., Shidvar, F., \& Gohari, M. R. (2014). The Impact of Training on Women's Capabilities in Modifying Their Obesity-Related Dietary Behaviors: Applying Family-Centered Empowerment Model. Journal of Research in Health Science, 14(1). 76-81. Retrieved from https://www.ncbi.nlm.nih.gov/pubmed/24402855

Anderson, C. A., Gentile, D. A., \& Buckley, K. E. (2007). Violent video game effects on children and adolescents: Theory, research and public policy .https://doi.org/10.1093/acprof:oso/9780195309836.001.0001

Baum. F., \& Smith, D. (2006). Participatory Action Research. Oxford University. https://doi.org/10.1136/jech.2004.028662

Beck, C. A. J., \& Sales, B. D. (2001). Family mediation: Facts, myths, and future prospects (pp. 100-102). Washington, DC: American Psychological Association. https://doi.org/10.1037/10401-000.

Bernstein, T. M. (1965). The careful writer: A modern guide to English usage (2nd ed.). New York, NY: Atheneum.

Bjork, R. A. (1989). Retrieval inhibition as an adaptive mechanism in human memory. In H. L. Roediger III, \& F. 
I. M. Craik (Eds.), Varieties of memory \& consciousness (pp. 309-330). Hillsdale, NJ: Erlbaum.

Black, J. M. (2011). Medical Surgical Nursing, Clinikal Management for Positive Outcome ( $7^{\text {th }}$ ed.). Philadelphia. United Stated of America.

Clark. D. W. (2011). Preventive Medicine for The Doctor in his Community: an Epidemiologic Approach. American Journal of Public Health and TheNations Health, 48(7). 947. https://doi.org/10.2105/AJPH.48.7.947-a

Cress, C. M. (2009). Curricular strategies for student success and engaged learning [PowerPoint slides]. Retrieved from http://www.vtcampuscompact.org/2009/TCL_post/presenter_powerpoints/Christine\%20 Cress\%20-\%20Curricular\%20Strategies.ppt

Creswell, J. W., (2014). Research Design PendekatanKualitatif, KuantitatifdanMixed. Edisike 3.Yogyakarta.

Denzin, N. K., \& Lincoln, Y. S. (2009).Handbook of Qualitative Research. California USA: Sage Publication.

Driedger, S. D. (1998). After divorce.Maclean's, 111(16), 38-43.

Friedman. M. M., Bowden, V. R., \& Jones, E. G. (2010). Family Intervention: Research, Theory and Practice $\left(7^{\text {th }}\right.$ ed.). New Jersey: Pearson Education, Inc.

Gibbs, J. T., \& Huang, L. N. (Eds.). (1991). Children of color: Psychological interventions with minority youth. San Francisco, CA: Jossey-Bass.

Gilbert, D. G., McClernon, J. F., Rabinovich, N. E., Sugai, C., Plath, L. C., Asgaard, G., ... Botros, N. (2004). Effects of quitting smoking on EEG activationand attention last for more than 31 days and are more severe with stress,dependence, DRD2 A 1 allele, and depressive traits. Nicotine and TobaccoResearch, 6, 249-267. https://doi.org/10.1 080/1462220041 0001676305

Goleman, D. (2009). What makes a leader? In D. Demers (Ed.), AHSC 230: Interpersonal communication and relationships (pp. 47-56). Montreal, Canada: Concordia University Bookstore. (Reprinted from Harvard Business Review, 76(6), pp.93-102, 1998).

Guignon, C. B. (1998). Existentialism.In E. Craig (Ed.), Routledge encyclopedia of philosophy (Vol. 3, pp. 493-502). London, England: Routledge.

Healey, D. (2005). Attention deficit/hyperactivity disorder and creativity: An investigation into their relationship (Unpublished doctoral dissertation). University of Canterbury, Christchurch, New Zealand.

Herculano-Houzel, S., Collins, C. E., Wong, P., Kaas, J. H., \& Lent, R. (2008).The basic nonuniformity of the cerebral cortex. Proceedings of the National Academy of Sciences, 105, 12593-12598. https://doi.org/10.1073/pnas.0805417105

Holzemer, E. M. (2011). Modifying Risk Factors After TIA and Stroke: The Impact of Intensive Education. The Journal for Nurse Practitioners, 7(5), 372-377. https://doi.org/10.1016/j.nurpra.2011.01.017.

Hurlock, E. B. (2011). PsikologiPerkembangan: Suatu Pendekatan Sepanjangsentang Kehidupan. Jakarta: Erlangga.

Jager, K. B. (2003). Family Empowerment: A qualitative inquiry of the implications for family-based services. Regional Research Institute for Human Services. Portland State University.

Katz, M. D., David, L., \& Ali, A. (2015). Disease Prevention and Health Promotion: How Integrative Medicine fits. American Journal of Preventive Medicine, 49, 230-240. https://doi.org/10.1016/j.amepre.2015.07.019

Kemenkes, R. I. (2013). Pedoman Pengendalian Stroke, Direktor at Pengendalian Penyakit Tidak Menular, Subdit Pengendalian Penyakit Jantungdan Pembuluh Darah. Jakarta.

Kemmis.S., Mc Taggart, R., \& Nixon. (2014). The Action Research Planner, Doing Critical Participatory Action Research. London: Springer.https://doi.org/10.1007/978-981-4560-67-2

Klimoski, R., \& Palmer, S. (1993). The ADA and the hiring process in organizations. Consulting Psychology Journal: Practice and Research, 45(2), 10-36.https://doi.org/10.1037/1061-4087.45.2.10.

Kubrick, S. (Director). (1980). The Shining. United States: Warner Brothers.

Lewis. S. (2007). Medical Surgical Nursing ( $7^{\text {th }}$ ed.). St. Louis: Missouri. Mosby-Year Book, Inc.

Liu, S. (2005, May). Defending against business crises with the help of intelligent agent based early warning solutions. Paper presented at the Seventh International Conference on Enterprise Information Systems, 
Miami, FL. Abstract retrieved from http://www.iceis.org/iceis2005/abstracts_2005.htm

Lunenburg.F.C. (2010).Managing Change: The Role of The Change Agen. San Housten State University.

MacIntyre, L. (2002). Scandal of the Century. In H. Cashore (Producer), The fifth estate. Toronto, Canada: Canadian Broadcasting Corporation.

McLuhan, M. (1970a). Culture is our business. New York, NY: McGraw-Hill.

McLuhan, M. (1970b). From cliche to archetype. New York, NY: Viking Press.

Mellers, B. A. (2000). Choice and the relative pleasure of consequences. Psychological Bulletin, 126, 910-924. https://doi.org/10.1037/0033-2909.126.6.910.

Noorkhairina, S. (2013). Secondary Stroke Prevention Through Patient Education Intervention on Lifestyle Risk Factor. Health and the Environment Journal, 4, 127-151.

Polit, D., \& Beck, C. T. (2016). Nursing Research: Generating and AccesingAvidence for Nursing Practice $\left(10^{\text {th }}\right.$ ed.). Philadelphia: Lippincot.

Postman, N. (1979).Teaching as a conserving activity. New York, NY: Delacorte Press.

Postman, N. (1985).Amusing ourselves to death: Public discourse in the age of show business. New York, NY: Viking.

Semenak, S. (1995, December 28). Feeling right at home: Government residence eschews traditional rules. Montreal Gazette, p. A4.

Senoo, K., Gregory, R., \& Lip, M. (2015). Relationship of Age with Stroke and Death in Anticoagulated.Birmingham, United Kingdom and Aalborg Thrombosis Research Unit. Department of Clinical Medicine, Aalborg University, Aalborg, Denmark.

Sikhong, K. (2015). Blood Pressure Management for Stroke Prevention and in Acute Stroke.Journal of Stroke, 19.152-165. https://doi.org/10.5853/jos.2017.00164

Smeltzer, S., \& Bare, B. (2010). Text book. Medical Surgical of Nursing; Bruner and Suddarth (12 ${ }^{\text {th }}$ ed.). Philadelpia, New York.

Strong, E. K. Jr., \& Uhrbrock, R. S. (1923). Bibliography on job analysis. In L. Outhwaite (Series Ed.), Personnel Research Series: Vol. 1. Job analysis and the curriculum (pp. 140-146). https://doi.org/10.1037/10762-000.

Whiteside, M., Tsey, K., James, Y. C., \& McCalman, J. (2014). The Family Wellbeing Empowerment Aproach. Springer Cham Heidelberg New York Dordrecht London. https://doi.org/10.1007/978-3-319-04618-1_1

World Health Organisation. (2015). International Classification of Functioning (ICF). Disability and Health.

Yayasan Stroke Indonesia. (2012). FaktorRisiko stroke Meningkat. Yastroki: Jakarta.

\section{Copyrights}

Copyright for this article is retained by the author(s), with first publication rights granted to the journal.

This is an open-access article distributed under the terms and conditions of the Creative Commons Attribution license (http://creativecommons.org/licenses/by/4.0/). 